THE ECONOMICS OF ENERGY 
Other titles from The Macmilan Education

Richard Lecomber: THE ECONOMICS OF NATURAL RESOURCES

David Pearce: The eConomics of Natural RESOURCE DEPLETION 


\title{
THE ECONOMICS OF ENERGY
}

\author{
MICHAEL G. WEBB \\ and \\ MARTIN J. RICKETTS
}


(C) Michael G. Webb and Martin J. Ricketts 1980

All rights reserved. No part of this publication may be reproduced or transmitted, in any form or by any means, without permission.

First published in 1980 by

THE MACMILLAN PRESS LTD

London and Basingstoke

Associated companies in Delhi Dublin

Hong Kong Johannesburg Lagos Melbourne

New York Singapore and Tokyo

Typeset in 11/12 pt Press Roman by

STYLESET LIMITED

Salisbury $\cdot$ Wiltshire

\author{
British Library Cataloguing in Publication Data \\ Webb, Michael Gordon \\ The economics of energy. \\ 1. Power resources \\ I. Title II. Ricketts, Martin J \\ 333.7 HD9502.A2 \\ ISBN 978-0-333-24496-8 ISBN 978-1-349-16323-6 (eBook) \\ DOI 10.1007/978-1-349-16323-6
}

This book is sold subject to the standard conditions of the Net Book Agreement.

The paperback edition of this book is sold subject to the condition that it shall not, by way of trade or otherwise, be lent, re-sold, hired out, or otherwise circulated without the publisher's prior consent in any form of binding or cover other than that in which it is published and without a similar condition including this condition being imposed on the subsequent purchaser. 
To Diana and Veronica 


\section{CONTENTS}

Preface $\quad$ xi

Acknowledgements $\quad$ xii

1 INTRODUCTION 1

2 STATISTICAL BACKGROUND 8

2.1 Introduction 8

The changing pattern of world energy
consumption

Energy consumption trends in the United
Kingdom and the United States

2.4 Energy production 16

2.5 Energy reserves 19

2.6 Non-conventional energy sources 22

3 THE DEPLETION OF ENERGY RESOURCES 27

3.1 Introduction 27

3.2 Inter-temporal choice 30

3.3 Resource depletion: some positive theory 37

3.4 Resource depletion: some formal normative
approaches

3.5 Is depletion too fast? 66

$\begin{array}{ll}3.6 \text { Conclusions } & 72\end{array}$

4 ENERGY PRICING 74

4.1 Introduction $\quad 74$

4.2 Interdependence of pricing and investment
decisions

4.3 Objectives and constraints $\quad 78$

4.4 Marginal cost pricing $\quad 79$

4.5 Peak-load pricing 95 
4.6 Feasible storage with a heterogeneous production technology $\quad 89$

4.7 Evaluation 93

4.8 Measures of marginal cost $\quad 97$

4.9 Financial targets 102

4.10 Equity 105

4.11 Conclusions 109

5 ENERGY AND THE ENVIRONMENT 111

5.1 Introduction 111

5.2 Energy-associated environmental effects 111

5.3 Some evidence on energy-related pollution 121 emissions

$\begin{array}{lll}5.4 & \text { Pollution control policy } & 126\end{array}$

5.5 Problems of application 133

5.6 Policy in practice 139

5.7 Conclusions 142

6 FISCAL INSTRUMENTS OF ENERGY POLICY 144

6.1 Introduction 144

6.2 Taxes and the depletion rate 146

6.3 Taxes and economic rent 157

6.4 Non-fiscal instruments 169

6.5 U.K. taxation in the North Sea 173

6.6 Uranium royalties in Saskatchewan 179

6.7 Some issues in North American tax policy 183

6.8 Conclusion 189

7 UNCERTAINTY AND ENERGY POLICY 191

7.1 Introduction 191

7.2 Markets and uncertainty 192

7.3 Exploration for oil - a numerical example 206

7.4 Public policy and the discount rate 210

7.5 Irreversibility and 'option value' 216

7.6 Problems of using probabilities 221

7.7 Decision theory 223

7.8 Implications for policy formulation 227

7.9 Conclusion 232 
8 ENERGY ANALYSIS 234

8.1 Introduction 234

8.2 Methodology 235

8.3 Choice of numéraire 238

8.4 Energy analysis and energy policy 243

8.5 Energy analysis and energy conservation 247

8.6 Energy analysis and investment appraisal 250

8.7 Conclusions 252

9 ENERGY POLICY 253

9.1 Introduction 153

9.2 The nature of energy policy 254

9.3 Energy policy in the United Kingdom 255

9.4 Energy policy in the United States 266

9.5 Economics and energy policy 271

$\begin{array}{ll}\text { Notes and References } & 275\end{array}$

$\begin{array}{ll}\text { Index } & 309\end{array}$ 


\section{PREFACE}

In recent years there has been a proliferation of books dealing with energy and particular aspects of energy economics. For the most part these books have been concerned with either particular energy industries, the general planning and formulation of energy policy or with the use and effects of specific policy instruments, such as the taxation of North Sea oil in the United Kingdom or the Federal regulation of interstate gas prices in the United States. It has been ouf objective in writing this book to provide an integrated and reasonably comprehensive introduction to the economics of energy. We chose not to devote separate chapters to the individual energy industries in the belief that this approach obscures the common set of problems which are associated with the development and use of the different forms of energy.

The analytical framework of the book is that of Paretian welfare economics. It is aimed primarily at undergraduates reading economics who have studied intermediate-level microeconomics. Thus we hope that it will be especially useful for students studying public policy economics, natural resource economics, applied economics and environmental economics. By making the book comprehensive and by providing extensive references we have tried to make most of it accessible to students in other disciplines, such as engineering and geography, who are studying topics within the subject area of energy economics. Similarly most of it should be comprehensible to those government officials who are concerned with questions of energy policy.

We would like to thank the Editor of Energy Policy for granting permission for us to use material in Chapters 4 and 8 from two articles by Michael Webb which were originally published in that journal. In addition we would like to thank Barbara Dodds, Barbara Jacques, Gail Shepherd, Tina Asu and Linda Waterman for typing the manuscript.

February 1979

MICHAEL G. WEB B MARTIN J. RICKETTS 


\section{ACKNOWLEDGEMENTS}

The authors and publishers wish to thank the following, who have kindly given permission for the use of copyright material:

Ballinger Publishing Company, for a table from Environmental Management, ed. G. F. Rohrlich, (c) 1976.

The Controller of Her Majesty's Stationery Office, for tables based on statistics from official publications.

The Ford Foundation, for a table in A Time to Choose, Energy Policy Project of the Ford Foundation, published by Ballinger Publishing Company, 1974, (c) The Ford Foundation.

Institute of Social and Economic Research, University of Alaska, for a table from Alaska's Petroleum Leasing Policy, by Gregg K. Erickson.

International Communication Agency, for a table from the National Energy Plan, Executive Office of the President, The White House, 29 April 1977.

Lexington Books, for an adaptation of a table in Economic Aspects of the Energy Crisis, by Harry W. Richardson (Lexington, Mass.: Lexington Books, D. C. Heath \& Co., (C) 1975, D. C. Heath \& Co.).

National Coal Board, for a table from National Coal Board Annual Reports and Accounts.

Shell International Petroleum Co. Ltd, for tables from 'Energy in Perspective' (1977) and 'A Generation of Change: World Energy Patterns 1950-1975' (1976), published in the Shell Briefing Service.

South Coast Air Quality Management District, for a table from 1974 Profile of Air Pollution Control, published by The Los Angeles Air Pollution Control District. 
Every effort has been made to trace all the copyright-holders, but if any have been inadvertently overlooked the publishers will be pleased to make the necessary arrangement at the first opportunity. 